\begin{tabular}{|l|l|l||}
\hline \multicolumn{2}{|c|}{ PublisherInfo } \\
\hline \hline PublisherName & $:$ & BioMed Central \\
\hline \hline PublisherLocation & $:$ & London \\
\hline \hline PublisherImprintName & $:$ & BioMed Central \\
\hline \hline
\end{tabular}

\title{
Preemptive SARS patents
}

\begin{tabular}{|l|l|l||}
\hline \multicolumn{2}{|c|}{ ArticleInfo } \\
\hline \hline ArticleID & $:$ & 4770 \\
\hline \hline ArticleDOI & $:$ & $10.1186 /$ gb-spotlight-20030512-01 \\
\hline \hline ArticleCitationID & $:$ & spotlight-20030512-01 \\
\hline \hline ArticleSequenceNumber & $:$ & 122 \\
\hline \hline ArticleCategory & $:$ & Research news \\
\hline ArticleFirstPage & $:$ & 1 \\
\hline \hline ArticleLastPage & $:$ & 3 \\
\hline \hline & & RegistrationDate : 2003-5-12 \\
\hline ArticleHistory & $:$ & OnlineDate \\
\hline \hline ArticleCopyright & $:$ & BioMed Central Ltd2003-5-12 \\
\hline \hline ArticleGrants & $:$ & \\
\hline \hline ArticleContext & $:$ & 130594411 \\
\hline \hline
\end{tabular}


Peg Brickley

Email: pegbrickley@hotmail.com

Canadian and U.S. officials say they have applied for patents on the SARS coronavirus genome in order to create an open field for researchers, not lock down future profits from tests or treatments for the disease. The University of Hong Kong's (UHK) commercial arm, Versitech Ltd., has also applied for a U.S. SARS patent, but North American rivals are voicing suspicion about UHK's motives.

"We're basically trying to preempt the nonsense that has gone on in the past," said Samuel Abraham, director of the technology development office at the British Columbia Cancer Agency in Vancouver, which led the filing for a group of Canadian researchers.

Nonetheless, the Canadian health agency's action touched off an internal debate, with some scientists balking at the idea of potentially reaping profits from the public health threat.

Patents on organisms' whole genomes or specific genes are not uncommon, and they permit patentholders to charge licensing fees for access to the sequence information - fees that many researchers feel are inappropriate for what they consider a discovery rather than an invention.

"Most research institutions and most scientists have a knee-jerk reaction when they hear a patent has been filed," Abraham said. "They read it as someone trying to corner the market. We're making sure the market is not cornered."

Similarly, the chief patent officer for the US Centers for Disease Control and Prevention (CDC) said the government agency filed for a patent only to make sure no one else blocked access to the virus.

"We made a decision early on to seek whatever patent protection we could get as a defensive measure, but not to delay publication of findings," said Andrew Watkins, a patent attorney and director of the CDC technology transfer office.

Asked whether he thought trouble might be brewing between the CDC-based patent applicants and Canadian and Chinese groups, Watkins said the Canadians seemed to be moving on the same course as the U.S. group. But Hong Kong is a different matter.

"To the extent there might be a competition, I don't think our goals are the same," Watkins said, referring to published accounts of the Hong Kong group's application.

In response to our inquiries, Versitech intellectual property officer Lisa Poon confirmed by e-mail that the university has filed for a SARS virus patent in the U.S. Poon noted that UHK has already provided virus samples to researchers around the world "in order to further research and development," but did not address how a future patent would be used.

The most likely outcome for the Canadian and U.S. applications, Watkins said, is a negotiated joint ownership that could include hundreds of "inventors" from different countries.

"If we're all trying to claim the same invention, including Hong Kong, then there would be an interference procedure in which the patent office would determine who was the first to invent," Watkins 
said. "It could be we'll wind up with a jointly owned single patent, and we have not done that analysis yet."

Even if the CDC's application wins, "the ultimate inventor list will be much longer than the CDC," Watkins said.

Boston biotech patent lawyer Thomas Saunders said the patent competition was not a set-up for a high-stakes tug of war. "It's probably a tempest in a teapot," Saunders said. "The problem with SARS is that it does not appear to be commercially attractive enough to attract interest in the first place."

For years to come, researchers intent on pursuing a SARS treatment are free to act, he added. "Patents do not issue in less than two or three years, so all of this sky-is-falling concern is unwarranted. Anyone today can take the information and work with it."

Watkins said the CDC's application does not purport to cover vaccines, diagnostic tests or other technology related to SARS. The patent is designed to make sure sequence data remains public, he said.

Abraham also pointed out that much remains to be determined, including whether the identified strains of coronavirus are the cause, or sole cause, of SARS.

"Having this information is a long way from having an effective drug," Saunders said. "This is no more than an opportunity to buy lottery tickets."

\section{References}

1. Brickley P: Staking claims Genome Biology, December 5, 2002., [http://genomebiology.com/ researchnews/default.asp?arx_id=gb-spotlight-20021205-04]

2. Hagan P: Crackdown on DNA patents needed The Scientist, July 23, 2002., [http://www.thescientist.com/news/20020723/03/]

3. Walgate R: SARS vaccine race The Scientist, May 2, 2003., [http://www.the-scientist.com/news/ 20030502/03/]

4. Walgate R: WHO says coronavirus causes SARS Genome Biology, April 17, 2003., [http://genomebiology.com/researchnews/default.asp?arx_id=gb-spotlight-20030417-01] 